\title{
Editorial
}

\section{Editorial from the Editor-in-Chief: People Matter!}

\author{
Wendy M. Purcell
}

check for

updates

Citation: Purcell, W.M. Editorial from the Editor-in-Chief: People Matter! Merits 2022, 2, 18-20. https://doi.org/10.3390/ merits2010002

Received: 27 January 2022

Accepted: 27 January 2022

Published: 30 January 2022

Publisher's Note: MDPI stays neutral with regard to jurisdictional claims in published maps and institutional affiliations.

Copyright: (C) 2022 by the author. Licensee MDPI, Basel, Switzerland. This article is an open access article distributed under the terms and conditions of the Creative Commons Attribution (CC BY) license (https:// creativecommons.org/licenses/by/ $4.0 /)$.
Harvard T.H. Chan School of Public Health, Harvard University, Boston, MA 02215, USA; wpurcell@hsph.harvard.edu

People are the focus of Merits, an international, peer-reviewed open access journal. Aligned through purpose, vision and values, people are agents of change. Despite this truth, we continue to speak in rather clinical terms of 'organizational change', when it is clear that organizations do not change-people do! Similarly, we narrate a change journey as a linear account-starting out here and ending up over there. This fails to capture the insights learned from peoples' struggles to effect change-the losses, false starts, the wins, stories of personal growth and adaptation.

Successfully navigating these current times, characterized by high degrees of volatility, uncertainty, complexity and ambiguity-so-called VUCA conditions [1]—will rely upon enabling people to flourish at work. Flourishing is multidimensional [2] and includes accomplishments, engagement, meaning, positive emotions and relationships; dignity, self-esteem and spiritual health are also part of flourishing [3]. The flourishing index is based around five central domains [4]: happiness and life satisfaction; mental and physical health; meaning and purpose; character and virtue; and close social relationships. Each of these is desired universally and each constitutes an end in and of itself; however, they are not universal, and part of our journey towards equity is to conceive of human flourishing as a human right and one that work can influence materially for the good.

Importantly, flourishing at work shows up in improved performance and productivity, and has profound positive effects on physical and mental health, in addition to well-being. Critically, there are now evidence-based ways to measure flourishing at work and determine the impact of interventions that seek to promote it $[3,4]$. This goes beyond a pulse or work climate survey, and measures the ability of employees to concentrate, perform and engage as well as markers of wellness.

Our basic psychological needs of autonomy, competence and relatedness need to be met [5] for us to flourish. Being connected with others and feeling cared for set us up for success and personal growth; we need to sense that we belong and that we truly matter, with opportunities to be heard and contribute. Greater autonomy enhances our intrinsic motivation, resulting in better performance that is sustained together with greater satisfaction and well-being [5]. It is here that leadership and governance can influence flourishing.

Leadership, defined as the ability to mobilize people to face new realities [6], and governance, the system(s) through which an organization operates and is controlled [7], are at a premium given the disruptive global megatrends affecting work and workplaces, from technology through to the climate crisis. Supporting productivity, performance and well-being relies on the ability and motivation of leaders at all levels to support flourishing as they embrace change by honoring the heritage of organizations in terms of their purpose and values [6] as they explore new horizons. In turn, governance systems need to be able to support more agile working, while ensuring business continuity, risk mitigation and resilience. As such, in these times of uncertainty and the emergence of the 'next normal', finding new ways to navigate VUCA times needs evidence-based and research-informed insights and solutions. This is where Merits can help develop the field and reflect the work of an exciting community of global scholars.

Leaders in pursuit of change must pay all due homage to acknowledging the important contributions of those who have gone before and the innovations of the past. Preparing 
those within an organization to accept that change is necessary does not mean diminishing in turn the dignity of those who served before or do so now [6,8]. Leaders need to articulate a clear and compelling change mandate and communicate a way forward that is optimistic. As 'peddlers in hope' [9], they need to be able to cultivate optimism in a better tomorrow to encourage followership [10] and support people to invest now in anticipation of betterment tomorrow-fueling the move from here to there.

Acting with compassion, honoring losses and trust building are all therefore essential change management tools and leadership practices. Compassion serves to amplify leadership competencies and is considered a differentiator for success. It is about 'feeling for' someone and wanting to help, different from empathy, which involves feeling with another that in itself may not be sustainable [11]. The complexity of transformational change journeys places greater emphasis on the ability of leaders to be able to simplify the 'Why?' of change against such a multifaceted change landscape.

Paying close attention to managing their emotional tone, being authentic, acting with integrity and seeking to build trust $[12,13]$, leaders need the humility to build relationships and trust in the face of VUCA conditions. These critical leadership competencies then extend a leader's remit beyond results and outcome measures to the very process of how change is enacted. Generative leadership and governance models that support strategic agility and accountability are therefore needed to create resilience and adaptive capacity for organizations to face new realities and play their fullest role in creating a world where 'no one will be left behind' [14].

Merits curates and shares leading-edge research in the field relevant to high-impact practices, thereby enabling the translation of knowledge to support the optimal performance of people at work. We invite your contribution to the field.

Funding: This research received no external funding.

Conflicts of Interest: The author declares no conflict of interest.

\section{References}

1. Bennis, W.; Nanus, B. The Strategies for Taking Charge; Leaders, Harper \& Row: New York, NY, USA, 1985.

2. Seligman, M.E.P. Flourish: A Visionary New Understanding of Happiness and Well-Being; Free Press: New York, NY, USA, 2011. Available online: https:/ / psycnet.apa.org/record/2010-25554-000 (accessed on 26 January 2022).

3. VanderWeele, T.J. On the Promotion of Human Flourishing. PNAS 2017, 114, 8148-8156. Available online: https:/ /www.pnas. org/content/pnas/114/31/8148.full.pdf (accessed on 26 January 2022). [CrossRef] [PubMed]

4. The Human Flourishing Program. Available online: https://hfh.fas.harvard.edu/measuring-flourishing (accessed on 26 January 2022).

5. Ryan, R.M.; Deci, E.L. Self-Determination Theory and the Facilitation of Intrinsic Motivation, Social Development, and Well-Being. Am. Psychol. 2000, 55, 68-78. Available online: https://psycnet.apa.org/buy/2000-13324-007 (accessed on 26 January 2022). [CrossRef] [PubMed]

6. Heifetz, R.A.; Linsky, M.; Grashow, A. The Practice of Adaptive Leadership: Tools and Tactics for Changing Your Organization and the World; Harvard Business Press: Boston, MA, USA, 2009.

7. Governance Today. Available online: https://www.governancetoday.com/GT/Material/Governance__what_is_it_and_why_is_ it_important_.aspx (accessed on 26 January 2022).

8. Hicks, D. Dignity: It's Essential Role in Resolving Conflict; Yale University Press: New Haven, CT, USA, 2011.

9. Owen, J. Myths of Leadership_Banish the Misconceptions and Become a Great Leader; Kogan Page Ltd.: London, UK, 2018.

10. Kellerman, B. Followership: How Followers Are Creating Change and Changing Leaders; Harvard Business School Press: Boston, MA, USA, 2008.

11. Hougaard, R. Four Reasons Why Compassion Is Better for Humanity than Empathy. Forbes. 2020. Available online: https:// www.forbes.com/sites/rasmushougaard/2020/07/08/four-reasons-why-compassion-is-better-for-humanity-than-empathy/ (accessed on 26 January 2022).

12. Frei, X.; Morriss, A. Begin with Trust. Available online: https://hbr.org/2020/05/begin-with-trust (accessed on 26 January 2022).

13. Goleman, D.; Boyatzis, R.E. Emotional Intelligence Has 12 Elements. Which Do You Need to Work on? 2017. Available online: https: / hbr.org/2017/02/emotional-intelligence-has-12-elements-which-do-you-need-to-work-on (accessed on 26 January 2022).

14. United Nations. Available online: https://sdgs.un.org/2030agenda (accessed on 26 January 2022). 
Short Biography of Author

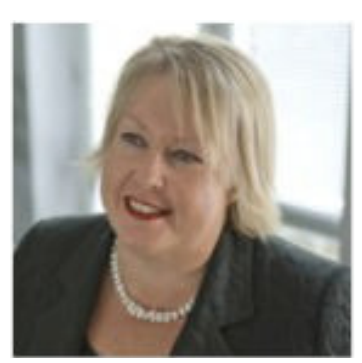

Wendy M. Purcell PhD FRSA (pronouns: she, her, hers), Harvard T.H. Chan School of Public Health, Harvard University. She leads research on global leadership and governance for sustainable transformation in various business sectors and higher education, and directs the Sustainable Development Solutions Group. Wendy is an Emeritus Professor and President Vice-Chancellor Emerita (UK university, 2007-2015), taking it to the top 1\% of world universities. The former NonExecutive Director to the UK Government's Department of Business, Innovation and Skills, and Chair of its Nominations (Talent) Committee, she advises the Cabinet Office on talent and diversity. She is an expert adviser to and Board Member of a range of global boards and charities, and is a registered Coach. wpurcell@hsph.harvard.edu. https://scholar.harvard.edu/wendypurcell; https://connects.catalyst.harvard.edu/Profiles/display/Person/152606. 